Hydrol. Earth Syst. Sci., 17, 2097-2105, 2013

www.hydrol-earth-syst-sci.net/17/2097/2013/

doi:10.5194/hess-17-2097-2013

(C) Author(s) 2013. CC Attribution 3.0 License.

\title{
Cyanobacterial and microcystins dynamics following the application of hydrogen peroxide to waste stabilisation ponds
}

\author{
D. J. Barrington ${ }^{1}$, A. Ghadouani ${ }^{1}$, and G. N. Ivey ${ }^{2}$ \\ ${ }^{1}$ Aquatic Ecology and Ecosystem Studies, M015, School of Environmental Systems Engineering, The University of Western \\ Australia, 35 Stirling Highway, Crawley, Australia \\ ${ }^{2}$ Geophysical Fluid Dynamics, M015, School of Environmental Systems Engineering, The University of Western Australia, \\ 35 Stirling Highway, Crawley, Australia
}

Correspondence to: D. J. Barrington (dani.barrington@monash.edu)

Received: 5 February 2013 - Published in Hydrol. Earth Syst. Sci. Discuss.: 18 February 2013

Revised: 7 May 2013 - Accepted: 9 May 2013 - Published: 5 June 2013

\begin{abstract}
Cyanobacteria and cyanotoxins are a risk to human and ecological health, and a hindrance to biological wastewater treatment. This study investigated the use of hydrogen peroxide $\left(\mathrm{H}_{2} \mathrm{O}_{2}\right)$ for the removal of cyanobacteria and cyanotoxins from within waste stabilization ponds (WSPs). The daily dynamics of cyanobacteria and microcystins (commonly occurring cyanotoxins) were examined following the addition of $\mathrm{H}_{2} \mathrm{O}_{2}$ to wastewater within both the laboratory and at the full scale within a maturation WSP, the final pond in a wastewater treatment plant. Hydrogen peroxide treatment at concentrations $\geq 0.1 \mathrm{mg} \mathrm{H}_{2} \mathrm{O}_{2} \mu \mathrm{g}^{-1}$ total phytoplankton chlorophyll $a$ led to the lysis of cyanobacteria, in turn releasing intracellular microcystins to the dissolved state. In the full-scale trial, dissolved microcystins were then degraded to negligible concentrations by $\mathrm{H}_{2} \mathrm{O}_{2}$ and environmental processes within five days. A shift in the phytoplankton assemblage towards beneficial Chlorophyta species was also observed within days of $\mathrm{H}_{2} \mathrm{O}_{2}$ addition. However, within weeks, the Chlorophyta population was significantly reduced by the re-establishment of toxic cyanobacterial species. This re-establishment was likely due to the inflow of cyanobacteria from ponds earlier in the treatment train, suggesting that whilst $\mathrm{H}_{2} \mathrm{O}_{2}$ may be a suitable short-term management technique, it must be coupled with control over inflows if it is to improve WSP performance in the longer term.
\end{abstract}

\section{Introduction}

Cyanobacteria are a common occurrence in waste stabilisation ponds (WSPs), a suspended growth biological treatment technology used in outdoor municipal wastewater treatment plants (WWTPs) (Furtado et al., 2009; Ho et al., 2010; Martins et al., 2011; Vasconcelos and Pereira, 2001). Several genera produce toxins, including microcystins, which pose a significant health risk to humans and animals. Both cyanobacteria and their toxins (cyanotoxins) are thus a substantial threat to ecological systems (Christoffersen, 1996; de Figueiredo et al., 2004).

The presence of cyanotoxins in drinking and recreational waters is often of greater concern to water management authorities than their presence in WSPs. However, as well as their inherent risk to human and ecological health, cyanobacteria are a hindrance to the wastewater treatment processes (Martins et al., 2011). Cyanobacteria and cyanotoxins inhibit the biological, physical, and chemical treatment of wastewater. Hence, the presence of cyanobacterial blooms increases the possibility that inadequately treated effluent will be discharged, possibly containing harmful cyanotoxins.

Previous investigations into the removal of cyanobacteria and cyanotoxins have generally been conducted on single species cultures and purified toxins under laboratory conditions. Limited knowledge is available regarding their removal from WSPs, even though treated wastewater is often used for irrigation or returned to the environmental flow (Toze, 2006). Although it is common practice to remove cyanobacteria using copper sulfate, chlorine, or coagulants

Published by Copernicus Publications on behalf of the European Geosciences Union. 
and flocculants (Hrudey et al., 1999), the dynamics of the removal of cyanobacteria and cyanotoxins from wastewater have not been thoroughly investigated. Additionally, the cyanobacterial removal methods currently practiced may negatively impact the environment, and may not be effective at removing cyanotoxins (Hrudey et al., 1999; Kenefick et al., 1993).

Hydrogen peroxide $\left(\mathrm{H}_{2} \mathrm{O}_{2}\right)$ has shown promise in reducing cyanobacteria and cyanotoxin concentrations, with increased success when coupled with other chemicals or radiation (Cornish et al., 2000; Drábková et al., 2007; Matthijs et al., 2012). Hydrogen peroxide does not accumulate in the environment, as it is decomposed rapidly to water and oxygen gas via biological, chemical and photochemical mechanisms (Cooper et al., 1994; Drábková et al., 2007). The chemical inhibits photosynthetic activity in cyanobacteria by impairing electron transfer and oxygen evolution, which can lead to the inactivation of photosystem II, and eventually cellular death (Samuilov et al., 2004). Because cyanobacteria are prokaryotic, this probably occurs more rapidly than when $\mathrm{H}_{2} \mathrm{O}_{2}$ is applied to eukaryotic cells, such as chlorophytes, whose photosynthetic apparatus are contained within discrete organelles. This suggests that $\mathrm{H}_{2} \mathrm{O}_{2}$ may be selective for cyanobacteria in mixed phytoplankton assemblages (Barrington and Ghadouani, 2008; Barroin and Feuillade, 1986). Hydrogen peroxide also forms hydroxyl and hydroperoxyl radicals which destroy the toxicity of cyanotoxins, such as microcystins, by inducing oxidative cleavage (Antoniou et al., 2008).

Following the addition of $\mathrm{H}_{2} \mathrm{O}_{2}$, the dynamics of cyanobacteria and cyanotoxins must be investigated before it can be recommended for use in cyanobacterial control. Most previous studies into the removal of cyanobacteria and cyanotoxins using $\mathrm{H}_{2} \mathrm{O}_{2}$ have not assessed the potential consequences of environmental and WSP conditions, although a recent study by Matthijs et al. (2012) has investigated the application of $\mathrm{H}_{2} \mathrm{O}_{2}$ to a lake. Many biological, chemical and physical variables may moderate the effective reduction of ecological assemblages of cyanobacteria and cyanotoxins by $\mathrm{H}_{2} \mathrm{O}_{2}$ (Barrington et al., 2011; Harada and Tsuji, 1998; Matthijs et al., 2012).

It has been suggested that when released from cyanobacterial cells, dissolved cyanotoxins may be degraded by environmental mechanisms within days to weeks (Harada and Tsuji, 1998). Hydrogen peroxide promotes cell lysis, and if cyanotoxins are not degraded by the chemical itself, their degradation by natural mechanisms is of significance. It has been demonstrated that the bacteria found in activated sludge effluent (produced during wastewater treatment) are able to degrade cyanotoxins, particularly microcystin species (Ho et al., 2010; Lam et al., 1995). In particular, Ho et al. (2010) compared the degradation rates of dissolved microcystins in both fresh activated sludge treated effluent and axenic tertiary-activated sludge treated effluent within the laboratory. Ho et al. (2010) determined that indigenous bacteria in WSPs are capable of degrading microcystins within days. This study also found that there was little reduction of microcystins in sterilised water, indicating that under laboratory conditions, biodegradation processes are more likely to remove microcystins than physical processes (Ho et al., 2010).

The work presented here investigates the effects of $\mathrm{H}_{2} \mathrm{O}_{2}$ addition on cyanobacteria and cyanotoxins, particularly microsystins, both within the laboratory and at a full-scale WSP. More specifically, the objectives were to (1) determine the dynamics of intracellular and dissolved microcystins following $\mathrm{H}_{2} \mathrm{O}_{2}$ treatment, (2) investigate the coupling between cyanobacterial lysis and microcystins release following the addition of $\mathrm{H}_{2} \mathrm{O}_{2}$ to a large scale cyanobacterial bloom under environmental conditions, and (3) investigate the longer term ( $\sim$ one month) effects of $\mathrm{H}_{2} \mathrm{O}_{2}$ treatment on the WSP assemblage.

\section{Methods}

\subsection{Study site}

Laboratory trials were performed to determine the dynamics of cyanobacteria and microcystins removal by various $\mathrm{H}_{2} \mathrm{O}_{2}$ concentrations at the microcosm scale, followed by $\mathrm{H}_{2} \mathrm{O}_{2}$ application to a full-scale WSP. Samples from the Water Corporation's Merredin WWTP, a suspended growth biological treatment plant in the Wheatbelt Region of Western Australia, were selected for the laboratory trial. During the summer months, the phytoplankton assemblage in the Merredin WWTP is predominantly cyanobacteria of the genera Microcystis and Planktothrix, both known to produce microcystins. The full-scale trial was performed on a large cyanobacterial bloom in the $8091 \mathrm{~m}^{3}$ maturation WSP. The maturation WSP is the last pond in the WWTP, and such ponds are designed to be aerobic throughout (Tchobanoglous et al., 2003).

\subsection{Experimental design - laboratory trials}

Two trials were designed to investigate the effects of $\mathrm{H}_{2} \mathrm{O}_{2}$ on cyanobacteria and cyanotoxins within a controlled laboratory environment. In both trials, four $20 \mathrm{~L}$ glass aquariums were utilised so that microcystins could not be adsorbed to the microcosms (Ikawa et al., 1999), and covered in black polyethylene so that light could only enter via the free-water surface. The temperature of both trials was kept constant at $25^{\circ} \mathrm{C}$. The microcosms were subjected to low levels of light provided by two GE Polylux XLR860 Daylight $3250 \mathrm{Lm}$ fluorescent tubes. The samples were illuminated in a $13 \mathrm{~h}: 11 \mathrm{~h}$ light: dark cycle, reminiscent of the daylight cycle at the Merredin WWTP at the time of sample collection.

Previous studies into the use of $\mathrm{H}_{2} \mathrm{O}_{2}$ for cyanobacterial removal have defined concentrations of $\mathrm{H}_{2} \mathrm{O}_{2}$ as mass per unit volume of water. This definition does not consider that the concentration of $\mathrm{H}_{2} \mathrm{O}_{2}$ which will be effective in removing cyanobacteria and microcystins is determinant upon the 
amount of $\mathrm{H}_{2} \mathrm{O}_{2}$ consumed in competing reactions within the receiving water reservoir. Hydrogen peroxide will react with phytoplankton cells other than cyanobacteria as well as organic and inorganic matter other than cyanotoxins.

Wastewater contains many biological and chemical constituents and, to allow for the use of $\mathrm{H}_{2} \mathrm{O}_{2}$ in various WSPs, a $\mathrm{H}_{2} \mathrm{O}_{2}$ concentration dependent upon a minimal number of such variables was required. It was established that within this study the most appropriate definition of $\mathrm{H}_{2} \mathrm{O}_{2}$ concentration could be determined by considering the mass of $\mathrm{H}_{2} \mathrm{O}_{2}$ per unit of phytoplankton chlorophyll $a$ ( $\mathrm{chl} a$ ), assuming that this also related to the magnitude of organic and inorganic matter within the WSP. Concentrations were calculated according to the measurement of total phytoplankton pigment concentration (defined as $\operatorname{chl} a$ ) in the water sample, determined by spectrofluorometry. This concentration definition is specific only to municipal wastewater concentrations, and would likely need to be adjusted if $\mathrm{H}_{2} \mathrm{O}_{2}$ were to be used within industrial wastewater, drinking water, or natural reservoirs. Although this concentration definition does make assumptions regarding the reactions between $\mathrm{H}_{2} \mathrm{O}_{2}$ and nontarget organisms and compounds, for such work it is a more accurate dose definition than using a mass of $\mathrm{H}_{2} \mathrm{O}_{2}$ per unit volume of water. This definition goes some way to considering competing reactions which will consume $\mathrm{H}_{2} \mathrm{O}_{2}$, without requiring extensive knowledge of the thousands of such reactions that occur under environmental conditions.

The first laboratory trial consisted of two control microcosms and two treated microcosms $\left(0.1 \mathrm{mg} \mathrm{H}_{2} \mathrm{O}_{2} \mu \mathrm{g}^{-1} \mathrm{chl} a\right.$, the concentration of $\mathrm{H}_{2} \mathrm{O}_{2}$ determined a priori to be appropriate for addition under field conditions (Barrington et al., 2011). As the cyanobacterial concentration present was exceptionally high $\left(\sim 25000 \mu \mathrm{g} \mathrm{chl} a \mathrm{~L}^{-1}\right)$, the required $\mathrm{H}_{2} \mathrm{O}_{2}$ concentration was $4000 \mathrm{mg} \mathrm{L}^{-1}$, which may be impractical for application to entire water bodies for economic reasons. However, such a dose may be applicable where surface scums, and not entire water bodies, require treatment. At the time of $\mathrm{H}_{2} \mathrm{O}_{2}$ addition, the $\mathrm{pH}$ of the microcosms was $\sim 7.8$. A second laboratory trial was performed using lower concentration cyanobacterial assemblages $\left(\sim 600 \mu \mathrm{g} \mathrm{chl} a \mathrm{~L}^{-1}\right)$. A control and three microcosms, each with a different concentration of $\mathrm{H}_{2} \mathrm{O}_{2}\left(0.02 \mathrm{mg} \mathrm{H}_{2} \mathrm{O}_{2} \mu \mathrm{g}^{-1}\right.$ chl $a, 0.2 \mathrm{mg}$ $\mathrm{H}_{2} \mathrm{O}_{2} \mu \mathrm{g}^{-1} \mathrm{chl} a$ and $2 \mathrm{mg} \mathrm{H}_{2} \mathrm{O}_{2} \mu \mathrm{g}^{-1}$ chl $a$ ) were prepared. Although this did not allow for replication, it was felt that trialing a variety of $\mathrm{H}_{2} \mathrm{O}_{2}$ concentrations would be beneficial to determining a suitable concentration to add in the full-scale trial. At the time of $\mathrm{H}_{2} \mathrm{O}_{2}$ addition, the $\mathrm{pH}$ of the microcosms was $\sim 8$.6. Within both laboratory trials, samples were collected for chl $a$ and microcystins analysis twice on the day of $\mathrm{H}_{2} \mathrm{O}_{2}$ treatment, and once daily for four days following treatment.

\subsection{Experimental design - full-scale field trial}

To investigate the dynamics of cyanobacteria and microcystins following $\mathrm{H}_{2} \mathrm{O}_{2}$ treatment under field conditions, a trial was performed in the maturation WSP at Merredin WWTP. As no Southwest Australian WWTPs consisting of parallel ponds suffered cyanobacterial blooms during the fieldwork period, there were no ponds available to act as controls or replicates. However, the bloom in the maturation WSP was predominantly cyanobacteria, and contained microcystins, and was thus chosen as an appropriate full-scale field trial site.

To achieve a $\mathrm{H}_{2} \mathrm{O}_{2}$ concentration of $0.1 \mathrm{mg}$ $\mathrm{H}_{2} \mathrm{O}_{2} \mu \mathrm{g}^{-1}$ chl $a, 1280 \mathrm{~L}$ of $50 \% \mathrm{H}_{2} \mathrm{O}_{2}$ was added to the WSP. The $\mathrm{H}_{2} \mathrm{O}_{2}$ was diluted with wastewater prior to addition, and was added via a surface jet to various points around the pond to ensure the maximum application across the surface. In previous work we determined that horizontal mixing by jet addition and wind-driven mixing was sufficient for spreading $\mathrm{H}_{2} \mathrm{O}_{2}$ throughout WSPs (Barrington et al., 2011). More $\mathrm{H}_{2} \mathrm{O}_{2}$ was added to the upwind side of the pond to ensure the maximum wind-driven spread of the chemical.

Following the addition of $\mathrm{H}_{2} \mathrm{O}_{2}$ to the Merredin maturation WSP, water was released gradually from the pond, and flow rates measured daily. It was determined from flow rate and pond volume measurements that retention time within the pond during the sampling period was approximately four weeks. Water samples representative of the top $50 \mathrm{~cm}$ of the water column were collected throughout this period, four times per week at the outlet of the WSP using a Van Dorn sampler. Weekly grab-samples were also taken at both the inlet and outlet of the WSP for microscopic phytoplankton cell counts.

\subsection{Phytoplankton biomass}

Phytoplankton biomass was primarily quantified through spectrofluorescence by use of the bbe Moldaenke FluoroProbe. During each sampling period, in each mesocosm and in the full-scale trial, ten measurements of cyanobacterial biomass were taken using the spectrofluorometer and their average calculated. The standard deviation of these ten measurements was always $<10 \%$ of the average value.

Spectrofluorescence measures the fluorescence of photosynthetic pigments using light emitting diodes at various wavelengths (Beutler et al., 2002; Ghadouani and Smith, 2005), and discriminates between different phytoplankton groups by measuring their fluorescence spectra. The FluoroProbe processing software converts the fluorescence of the pigments chl $a$, chlorophyll $c$, phycocyanobilin, phycoerythrobilin, fucoxanthin, and peridinin into units of equivalent chl $a$ (Beutler et al., 2002; Gregor and Marsalek, 2004). This method allows for the determination of fluorescence contributed by the phytoplankton groups Chlorophyceae, 
Cyanophyceae, Dinophyceae and Bacillariophyceae, and Cryptophyceae.

The FluoroProbe has been used as a measure of phytoplankton photosynthetic activity in previous studies (e.g. Beutler et al., 2002; Gregor and Marsalek, 2004), and was determined to be an appropriate proxy measurement for phytoplankton biomass within this work. The measurement of in vivo fluorescence allows the detection of changes to photosystem II, which indicates when cells are experiencing photoinhibition or photochemical inhibition (Samuilov et al., 1999, 2004). Although phytoplankton cells have repair mechanisms for damage to photosystem II, where the damage is severe, cells will likely die. The resulting absence of fluorescence indicates a reduction in phytoplankton biomass (Masojídek et al., 2011).

Additionally, weekly microscopic phytoplankton cell counts were performed by preserving samples in Lugol's iodine and adding to a Sedgewick Rafter Chamber. Samples were enumerated to the genus level by counting 25 to 30 fields within the chamber, according to the methods detailed in Hötzel and Croome (1999).

\subsection{Microcystins concentration determination}

In each measurement period one sample was collected for dissolved cyanotoxin analysis. This sample was filtered through $47 \mathrm{~mm}$ GF/C papers immediately following collection. Filter papers containing the intracellular microcystins fraction were frozen in triplicate at $-20^{\circ} \mathrm{C}$ prior to toxin extraction. Methanol was added to the filtrate (which contained the dissolved microcystins fraction) at $1 \%(\mathrm{v} / \mathrm{v})$.

Intracellular microcystins were extracted in triplicate for each sampling interval, using an adaptation of the methods described by Lawton et al. (1994). Filters were freeze thawed (thaw cycle at $20^{\circ} \mathrm{C}$, freeze cycle at $-20^{\circ} \mathrm{C}$ ) three times to lyse cyanobacterial cells prior to methanol extraction. Thawed filters were submerged in $5 \mathrm{~mL}$ of $75 \%$ methanol in nanopure water $(\mathrm{v} / \mathrm{v})$, sonicated on ice for $25 \mathrm{~min}$, and shaken on a rotary plate for $25 \mathrm{~min}$. The extracts were separated from filter papers and centrifuged at $3750 \mathrm{rpm}$ for $10 \mathrm{~min}$ at room temperature. The supernatant was transferred into a conical flask, and each filter paper further extracted twice. The three extracts were combined and diluted to $20 \%$ methanol in nanopure water $(\mathrm{v} / \mathrm{v})$ before application to solid phase extraction.

Both the filtrate containing dissolved microcystins and the extracts containing intracellular microcystins were applied to solid phase extraction (Waters Oasis HLB) for clean up and concentration. Cartridges were conditioned with $5 \mathrm{~mL}$ of methanol followed by $5 \mathrm{~mL}$ of nanopure water. Samples were loaded at $<10 \mathrm{~mL}$ per minute. Cartridges were rinsed with $5 \mathrm{~mL}$ of $10 \%$ methanol in nanopure water $(\mathrm{v} / \mathrm{v})$, followed by $5 \mathrm{~mL}$ of $20 \%$ methanol in nanopure water $(\mathrm{v} / \mathrm{v})$, and eluted with $100 \%$ methanol $+0.1 \%$ trifluoroacetic acid (TFA) (v/v). Samples were evaporated to dryness under nitrogen at $40^{\circ} \mathrm{C}$ and stored at $-20^{\circ} \mathrm{C}$ until the day they were to be analysed by HPLC-PDA. On the day of analysis, samples were re-dissolved in $30 \%$ acetonitrile $(\mathrm{ACN})$ in nanopure water $(\mathrm{v} / \mathrm{v})$.

To determine microcystins concentrations, samples from each laboratory and full-scale trial were first analysed by high performance liquid chromatography coupled to photodiode array detection (HPLC-PDA) followed by liquid chromatography coupled to mass spectrometry (LC-MS) to confirm that chromatographic peaks were microcystins. Peaks with UV spectra characteristic of microcystins (Lawton et al., 1994; Meriluoto and Spoof, 2005) were identified by HPLC-PDA at $238 \mathrm{~nm}(1.2 \mathrm{~nm}$ resolution) using the gradient detailed in Lawton et al. (1994), but with a maximum acetonitrile concentration of $100 \%$. The HPLC-PDA system used was a Waters Alliance 2695 instrumentation with PDA detector and an Atlantis T3 separation column $(3 \mu \mathrm{m}, 100 \AA$, $4.6 \times 150 \mathrm{~mm}$ i.d.). Analysis of peaks was performed using Empower (version 2). The molecular masses of the microcystins were identified by LC-MS using an Agilent 1200 series capillary pump with a 6340 Ion Trap mass selective detector, using the same separation column as for the HPLC. Mass analysis was performed by electrospray ionisation in positive mode, and data analysis conducted using ChemStation (version 3.4).

Three peaks were apparent in the HPLC-PDA and LCMS chromatograms which had both UV spectra and masses characteristic of microcystins (masses listed in International Organization for Standardization, 2005). These peaks, microcystin-LR, microcystin-FR and microcystin-WR, were identified within samples from both the laboratory and fullscale trials. Although it is possible that there were other microcystins present in the samples, these were the only toxins which could be conclusively identified, and were thus chosen to represent the characteristic behaviour of microcystins following $\mathrm{H}_{2} \mathrm{O}_{2}$ treatment within these studies. These three microcystin species were quantified using HPLC-PDA and a commercially available microcystin-LR standard (Sapphire Bioscience, Australia). Total microcystins concentrations were calculated as the sum of intracellular and dissolved cyanotoxins.

\subsection{Data analyses}

Statistical analyses were conducted using SigmaPlot (version 8.0). Standard errors were calculated for the first laboratory trial, but could not be calculated for the second laboratory trial or the full-scale trial, due to the lack of replication. In the full-scale trial, exponential curve fits were used to explain the behaviour of chl $a$ and microcystins in the longer term. The apparent behaviour of phycocyanin fluorescence immediately following $\mathrm{H}_{2} \mathrm{O}_{2}$ treatment was described by a logarithmic growth model. 


\section{Results and discussion}

\subsection{Cyanobacterial dynamics}

In most of the laboratory samples treated with $\mathrm{H}_{2} \mathrm{O}_{2}$, cyanobacterial chl $a$ appeared to increase in the $24 \mathrm{~h}$ immediately following $\mathrm{H}_{2} \mathrm{O}_{2}$ treatment. A significant reduction in cyanobacterial chl $a$ was not observed until one to three days following addition (Figs. 1c, 2e and g). This apparent increase in cyanobacteria was likely an artefact of chl- $a$ measurement using the FluoroProbe. This spectrofluorometer estimates the total cell chl $a$ by measuring the characteristic spectra of photosynthetic antenna pigments after excitation with visible light, and converting the pigment concentration to chl $a$ equivalents (Beutler et al., 2002). Upon cyanobacterial cell lysis following $\mathrm{H}_{2} \mathrm{O}_{2}$ treatment, the pigment phycocyanin may be released to the extracellular, dissolved state. Recent work suggests that the release of phycocyanin may increase the apparent concentration of cyanobacterial chl $a$ when measured using spectrofluorometry (Bastien et al., 2011; Moldaenke, 2009).

To confirm this, we performed a similar investigation to Moldaenke (2009) in our laboratory by sonicating cyanobacterial samples for seventy minutes to induce cell lysis. The cyanobacterial biomass of samples was measured in five minute intervals until no further increase in phycocyanin was observed. Results were normalised to an unsonicated control, and there was a maximum apparent chl $a$ increase of $53 \%$ following the release of phycocyanin to the dissolved phase (logarithmic growth, $R_{\text {adj }}^{2}=0.81$, ANOVA, $P=0.0002$, results not shown).

Phycocyanin is isomerised by high $\mathrm{pH}$ and urea concentrations (Berns and Maccoll, 1989), both common conditions in WSPs, and hence the dissolved pigment is not detected by spectrofluorometry within hours to days of cell lysis. This results in an apparent lag in cyanobacterial reduction following $\mathrm{H}_{2} \mathrm{O}_{2}$ addition. However, in our study cyanobacterial reduction certainly occurred following the addition of $\mathrm{H}_{2} \mathrm{O}_{2}$, indicated by visual observations of mass cell death.

The final concentrations of cyanobacterial chl $a$ in the laboratory trials, several days after $\mathrm{H}_{2} \mathrm{O}_{2}$ treatment, were likely indicative of chl $a$ concentrations contained within the remaining live cyanobacterial cells. However, measurements collected immediately following $\mathrm{H}_{2} \mathrm{O}_{2}$ treatment in all trials were probably heavily influenced by dissolved phycocyanin concentrations. This suggests that short-term measurements of antenna pigments may not reflect the overall behaviour of cyanobacterial colonies, particularly if blooms are collapsing from human intervention or natural means. This is an important consideration for water managers, as many technologies for determining algal biomass using chl $a$ and phycocyanin fluorescence are currently being developed and commercialized (see for example Gregor and Marsalek, 2004; Izydorczyk et al., 2005; Richardson et al., 2010).
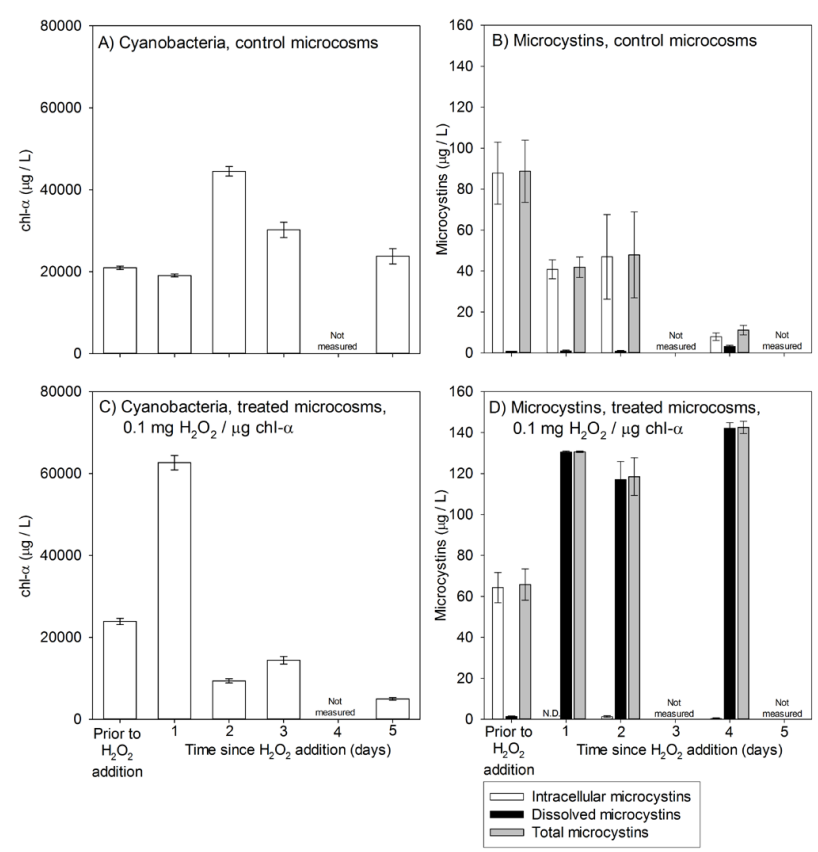

Fig. 1. Results from the first laboratory trial. (A) and (B) demonstrate cyanobacteria and microcystins dynamics in the control microcosms, whilst (C) and (D) demonstrate their behaviour in the treated microcosms. All microcystins concentrations are expressed as microcystin-LR equivalents. Error bars represent standard errors where $N=2$.

In the field experiment, cyanobacteria at the pond outlet decreased significantly in the week following $\mathrm{H}_{2} \mathrm{O}_{2}$ treatment, and then exhibited exponential growth (ANOVA, $P<0.01$ ) for the final three weeks of the monitoring period (Fig. 3a). This was probably due to the influx of cyanobacteria from WSPs earlier in the treatment train (notice the increasing concentration of cyanobacteria at the pond inlet in Fig. 3b), compounded by the environmental conditions favouring cyanobacterial abundance.

\subsection{Microcystins dynamics}

Total microcystins concentrations increased throughout the sampling period in the control and lowest $\mathrm{H}_{2} \mathrm{O}_{2}$ treated microcosms in the second laboratory trial, indicating that microcystins were produced in both control and treated microcosms (Fig. $2 b$ and d). It has been suggested that stress conditions may favour the increased production of microcystins in cyanobacteria (Kurmayer, 2011; Wang et al., 2007), and that significant production can take place on the scale of hours (Wood et al., 2012). The rapid increase observed in this trial may have been stimulated by laboratory conditions and the addition of $\mathrm{H}_{2} \mathrm{O}_{2}$.

In the microcosms treated with $\geq 0.1 \mathrm{mg} \mathrm{H}_{2} \mathrm{O}_{2} \mu \mathrm{g}^{-1} \mathrm{chl} a$, intracellular microcystins concentrations decreased and dissolved microcystins concentrations increased (Figs. 1d, $2 f$ 

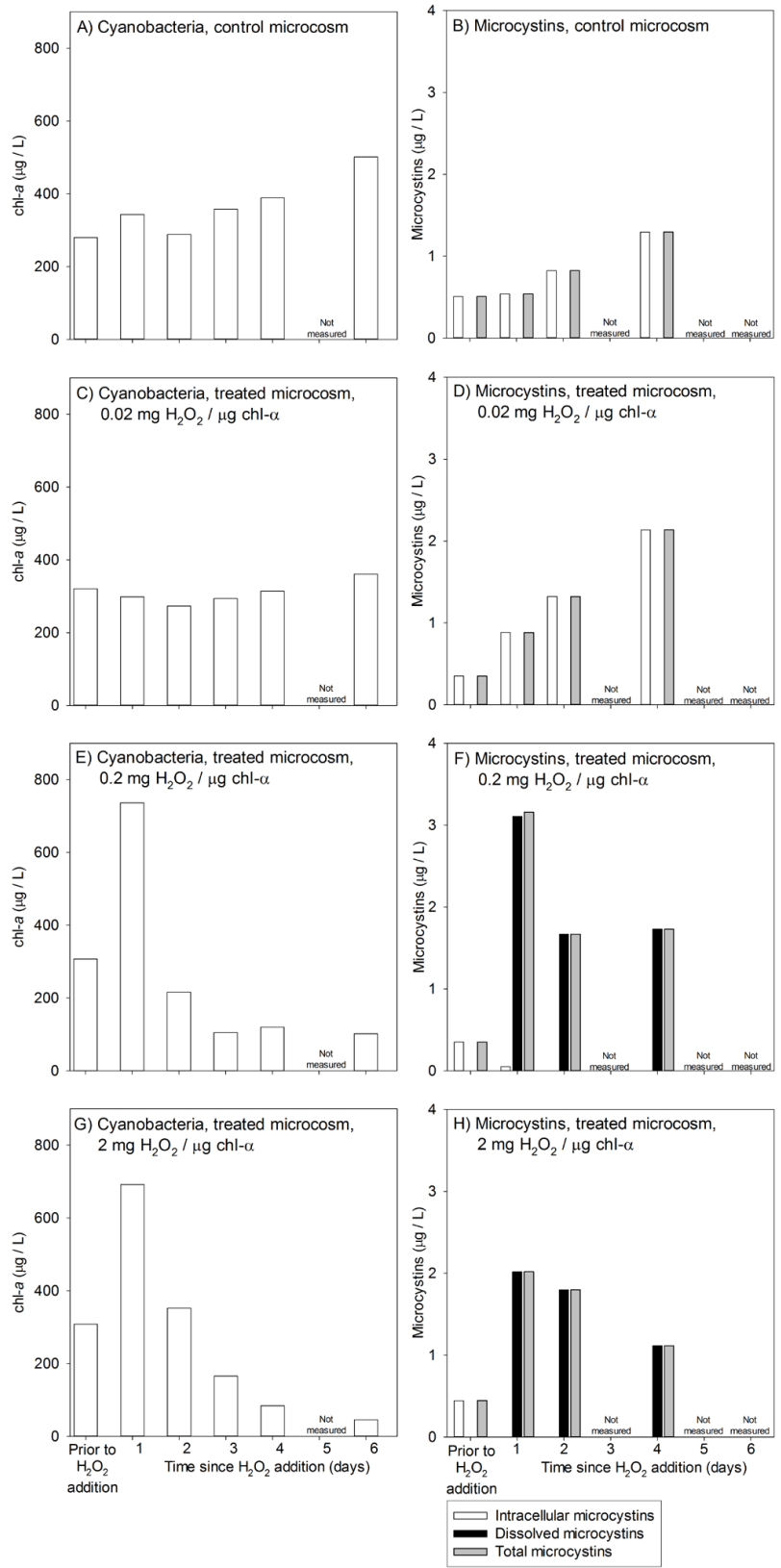

Fig. 2. Results from the second laboratory trial. (A) and (B) demonstrate cyanobacteria and microcystins dynamics in the control microcosms, whilst $(\mathbf{C}),(\mathbf{D}),(\mathbf{E}),(\mathbf{F}),(\mathbf{G})$ and $(\mathbf{H})$ demonstrate their behaviour in the treated microcosms. All microcystins concentrations are expressed as microcystin-LR equivalents.

and $h$ ). This indicates that where $\mathrm{H}_{2} \mathrm{O}_{2}$ was added at a concentration sufficient to induce cyanobacterial cell lysis, microcystins were released to the dissolved state. In the second laboratory trial (where $\mathrm{H}_{2} \mathrm{O}_{2}$ concentrations expressed as mass per unit volume were much smaller than in the first laboratory trial: the treated microcosms in laboratory trial 1 received $\sim 4 \mathrm{~g} \mathrm{~L}^{-1} \mathrm{H}_{2} \mathrm{O}_{2}$, whilst the treated microcosms in laboratory trial 2 received only $0.1-1 \mathrm{~g} \mathrm{~L}^{-1} \mathrm{H}_{2} \mathrm{O}_{2}$ ), dissolved
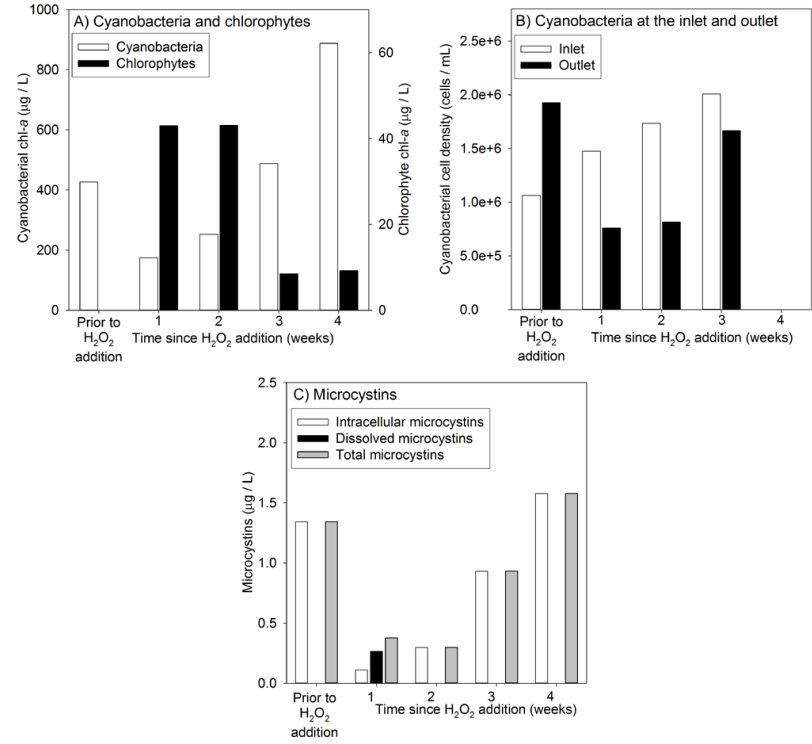

Fig. 3. Results from the Merredin waste stabilisation pond full-scale trial. Weekly averages are displayed in (A) and (C). (A) demonstrates changes in biomass of cyanobacteria and Chlorophyta (measured using spectrofluorescence) at the pond outlet, (B) the behaviour of cyanobacteria (measured as cell density) at both the inlet and outlet and $(\mathbf{C})$ the behaviour of intracellular and dissolved microcystins at the pond outlet. All microcystins concentrations are expressed as microcystin-LR equivalents.

microcystins concentrations decreased in the days following their release from cyanobacterial cells, indicating that some microcystins degradation was occurring within the water column (Fig. 2f and h). Hydrogen peroxide degrades within hours of addition (Cooper et al., 1994; Drábková et al., 2007), but dissolved microcystins will only be oxidised by $\mathrm{H}_{2} \mathrm{O}_{2}$ whilst it is still present within the water column, hence degradation by $\mathrm{H}_{2} \mathrm{O}_{2}$ was not the sole mechanism by which microcystins were decreased.

The degradation of microcystins by processes other than $\mathrm{H}_{2} \mathrm{O}_{2}$ addition is further illustrated by the results of the control microcosms of the first laboratory trial (Fig. 1b). A reduction in microcystins concentration within live cyanobacterial cells has not been observed in previous work, and extensive studies into the degradation of microcystins suggest that they are primarily degraded within the water column (World Health Organization, 2003). This suggests that in the control microcosms of the first laboratory trial (Fig. 1b) significant dissolved microcystins degradation occurred without $\mathrm{H}_{2} \mathrm{O}_{2}$ addition.

Bacterial degradation is a rapid natural mechanism for the removal of dissolved microcystins from the environment (Harada and Tsuji, 1998). It is likely that the significant decrease in dissolved microcystins in the control microcosms was due to the presence of natural bacteria in the WSP assemblage (Ho et al., 2010). The death of indigenous 
microcystins-degrading bacteria following the addition of $\mathrm{H}_{2} \mathrm{O}_{2}$ may explain why the degradation of dissolved microcystins in the treated microcosms of the first laboratory trial was minimal compared to controls. This may also explain why dissolved microcystins were degraded in treated microcosms of the second laboratory trial, where a lower $\mathrm{H}_{2} \mathrm{O}_{2}$ concentration (compared to the first laboratory trial) may not have killed all microcystins-degrading bacteria. Determining the response of microcystins-degrading bacteria to $\mathrm{H}_{2} \mathrm{O}_{2}$ addition requires further investigation.

In the full-scale trial intracellular microcystins were released to the dissolved phase immediately following $\mathrm{H}_{2} \mathrm{O}_{2}$ addition, and these dissolved microcystins were then degraded throughout the week following $\mathrm{H}_{2} \mathrm{O}_{2}$ addition (Fig. 3c). Although the processes occurring in the laboratory were likely also occurring in the field, the full-scale trial would have introduced further potential mechanisms for microcystins degradation, including the presence of UV radiation, which catalyses the production of hydroxyl and hydroperoxyl radicals from $\mathrm{H}_{2} \mathrm{O}_{2}$, resulting in a high degree of microcystins degradation in the hours following $\mathrm{H}_{2} \mathrm{O}_{2}$ addition (Glaze et al., 1987). Microcystins can also be destroyed by UV radiation through isomerisation, and photosensitised transformation in the presence of humic substances and pigments (Song et al., 2007; Tsuji et al., 1994; Welker and Steinberg, 1999, 2000). In the full-scale trial, there would also have been a significantly higher loading of sediment than in the laboratory trials, where wastewater was collected from the surface of ponds. Adsorption by sediments, and subsequent biodegradation, may have accelerated the reduction of microcystins in the full-scale trial compared to the laboratory trials (Harada and Tsuji, 1998; Liu et al., 2008). Biodegradation, UV radiation and adsorption may all have played a role in the longer term reduction of microcystins from the dissolved phase, and may have accelerated their reduction compared to the smaller scale trials under controlled laboratory conditions.

These studies indicate that the addition of $\mathrm{H}_{2} \mathrm{O}_{2}$ results in the release of microcystins to the dissolved phase but that a combination of $\mathrm{H}_{2} \mathrm{O}_{2}$ and natural mechanisms then degrade these dissolved toxins. This means that under field conditions the addition of $\mathrm{H}_{2} \mathrm{O}_{2}$ leads to a significant reduction in total microcystins, concurrently reducing the toxicity of the waterway. This suggests that $\mathrm{H}_{2} \mathrm{O}_{2}$ addition under environmental conditions may be suitable for reducing cyanotoxin concentrations in WSP assemblages. However, given the large variation between the laboratory and field results, it is imperative that further studies into the use of $\mathrm{H}_{2} \mathrm{O}_{2}$ are conducted in full-scale WSPs, particularly regarding the effects of $\mathrm{H}_{2} \mathrm{O}_{2}$ on microcystins-degrading bacteria.

\subsection{Cyanobacteria and Chlorophyta coupling in the full-scale trial}

The full-scale field trial was conducted for significantly longer than the laboratory trials, water was continuously flowing into the maturation pond, and the temperature could not be controlled. Hence the results of the full-scale trial demonstrate the longer-term behaviour of the cyanobacterial and phytoplankton assemblage following $\mathrm{H}_{2} \mathrm{O}_{2}$ addition, including influence of inflows and diurnal temperature fluctuations, which could not be investigated under laboratory conditions.

Prior to $\mathrm{H}_{2} \mathrm{O}_{2}$ treatment at the full scale, Chlorophyta, predominantly of the genera Chlamydomonas, Closterium, Scenedesmus, Monoraphidium, and Pandorina were present at low concentrations, particularly compared to cyanobacteria, at both the inlet and outlet of the Merredin maturation WSP (Chlorophyta $\sim 5000$ cells $\mathrm{mL}^{-1}$, cyanobacteria $\sim 2000000$ cells $\mathrm{mL}^{-1}$, data not shown). Chlorophyta are beneficial to WSPs, as they produce the oxygen required for wastewater treatment without significantly impacting upon treatment efficiency or posing a risk due to toxicity, unlike cyanobacteria. In the full-scale trial, the concentration of Chlorophyta at the outlet increased significantly in the two weeks following treatment with $\mathrm{H}_{2} \mathrm{O}_{2}$. Chlorophyta then decreased significantly in the third week following $\mathrm{H}_{2} \mathrm{O}_{2}$ treatment (Fig. 3a).

Several previous studies have determined that eukaryotic phytoplankton are less susceptible to $\mathrm{H}_{2} \mathrm{O}_{2}$ toxicity than prokaryotic cyanobacteria (e.g. Barrington and Ghadouani, 2008; Drábková et al., 2007). In the Merredin WSP, following $\mathrm{H}_{2} \mathrm{O}_{2}$ treatment, a large proportion of cyanobacteria was rapidly eliminated by $\mathrm{H}_{2} \mathrm{O}_{2}$, allowing the Chlorophyta a competitive advantage, and resulting in an increase in Chlorophyta abundance (Fig. 3a). However, in the subsequent weeks, cyanobacteria and intracellular microcystins exhibited exponential growth (ANOVA, $P<0.01$ ), with a resulting decrease in Chlorophyta concentration (Fig. 3). Cyanobacteria often dominate stratified reservoirs due to their ability to regulate their buoyancy, hence outcompeting other algae for light, and shading other organisms from incident radiation (Passarge et al., 2006). Whilst removing cyanobacteria from WSPs may allow the return of beneficial algal species, the continuing re-establishment of a pond with cyanobacteria (Fig. 3b) can rapidly reduce Chlorophyta abundance by competition. The phytoplankton assemblage of the WSP then returns to cyanobacterial dominance; probably with a resulting increase in microcystins (as observed in Fig. 3). 


\section{Conclusions}

Although $\mathrm{H}_{2} \mathrm{O}_{2}$ may be a short-term strategy for the removal of cyanobacteria and microcystins, processes within the WWTP which contribute to rapid cyanobacterial growth must also be assessed, so that re-establishment of the cyanobacterial colony does not occur soon after algicidal treatment. It is thus important to consider whether it would be beneficial to remove cyanobacteria and microcystins earlier in wastewater treatment, such that the following WSPs in the treatment train are not infected by a continuous inflow of cyanobacteria.

Acknowledgements. The authors are grateful to B. Kerenyi, C. Evans, D. O'Neill, J. Clark, B. Hatton, B. Hatton, G. Bertrand, D. Boland, S. C. Sinang, E. S. Reichwaldt, D. Krikke, R. Fenske, M. Timmins, G. Cawthray, M. Wallace, H. Barrington, and L. Coggins for their assistance with this study.

Edited by: A. D. Reeves

\section{References}

Antoniou, M. G., Shoemaker, J. A., De La Cruz, A. A., and Dionysiou, D. D.: Unveiling new degradation intermediates/pathways from the photocatalytic degradation of microcystin-LR, Environ. Sci. Technol., 42, 8877-8883, 2008.

Barrington, D. J. and Ghadouani, A.: Application of hydrogen peroxide for the removal of toxic cyanobacteria and other phytoplankton from wastewater, Environ. Sci. Technol., 42, 89168921, 2008.

Barrington, D. J., Ghadouani, A., and Ivey, G. N.: Environmental factors and the application of hydrogen peroxide for the removal of toxic cyanobacteria from waste stabilization ponds, J. Environ. Eng., 137, 952-960, 2011.

Barroin, G. and Feuillade, M.: Hydrogen peroxide as a potential algicide for Oscillatoria-Rubescens DC, Water Res., 20, 619623, 1986.

Bastien, C., Cardin, R., Veilleux, E., Deblois, C., Warren, A., and Laurion, I.: Performance evaluation of phycocyanin probes for the monitoring of cyanobacteria, J. Environ. Monit., 13, 110118, 2011.

Berns, D. S. and Maccoll, R.: Phycocyanin in physical-chemical studies, Chem. Rev., 89, 807-825, 1989.

Beutler, M., Wiltshire, K. H., Meyer, B., Moldaenke, C., Luring, C., Meyerhofer, M., Hansen, U. P., and Dau, H.: A fluorometric method for the differentiation of algal populations in vivo and in situ, Photosynth. Res., 72, 39-53, 2002.

Christoffersen, K.: Ecological implications of cyanobacterial toxins in aquatic food webs, Phycologia, 35, 42-50, 1996.

Cooper, W. J., Shao, C. W., Lean, D. R. S., Gordon, A. S., and Scully, F. E.: Factors affecting the distribution of $\mathrm{H}_{2} \mathrm{O}_{2}$ in surface waters, in: Environmental Chemistry of Lakes and Reservoirs, edited by: Baker, L. A., American Chemical Society, Washington, DC, 237, 391-422, 1994.

Cornish, B. J. P. A., Lawton, L. A., and Robertson, P. K. J.: Hydrogen peroxide enhanced photocatalytic oxidation of microcystin-
LR using titanium dioxide, Appl. Catal., B-Environ., 25, 59-67, 2000.

de Figueiredo, D. R., Azeiteiro, U. M., Esteves, S. M., Goncalves, F. J. M., and Pereira, M. J.: Microcystin producing blooms - a serious global public health issue, Ecotox. Environ. Safe., 59, 151-163, 2004.

Drábková, M., Admiraal, W., and Marsálek, B.: Combined exposure to hydrogen peroxide and light - Selective effects on cyanobacteria, green algae, and diatoms, Environ. Sci. Technol., 41, 309314, 2007.

Furtado, A. L. F. F., Calijuri, M. D., Lorenzi, A. S., Honda, R. Y., Genuario, D. B., and Fiore, M. F.: Morphological and molecular characterization of cyanobacteria from a Brazilian facultative wastewater stabilization pond and evaluation of microcystin production, Hydrobiologia, 627, 195-209, 2009.

Ghadouani, A. and Smith, R. E. H.: Phytoplankton distribution in Lake Erie as assessed by a new in situ spectrofluorometric technique, J. Great Lakes Res., 31, 154-167, 2005.

Glaze, W. H., Kang, J. W., and Chapin, D. H.: The chemistry of water treatment processes involving ozone, hydrogen peroxide and ultraviolet radiation, Ozone-Sci. Eng., 9, 335-352, 1987.

Gregor, J. and Marsalek, B.: Freshwater phytoplankton quantification by chlorophyll alpha: a comparative study of in vitro, in vivo and in situ methods, Water Res., 38, 517-522, 2004.

Harada, K. and Tsuji, K.: Persistence and decomposition of hepatotoxic microcystins produced by cyanobacteria in natural environment, J. Toxicol.-Toxin Rev., 17, 385-403, 1998.

Ho, L., Hoefel, D., Palazot, S., Sawade, E., Newcombe, G., Saint, C. P., Brookes, J. D.: Investigations into the biodegradation of microcystin-LR in wastewaters, J. Hazard. Mater., 180, 628-633, 2010.

Hötzel, G. and Croome, R.: A Phytoplankton Methods Manual for Australian Freshwaters, Land and Water Resources Research and Development Corporation: Canberra, 1999.

Hrudey, S. E., Burch, M. D., Drikas, M., and Gregory, R.: Remedial measures, in: Toxic cyanobacteria in water: a guide to their public health consequences, monitoring, and management, edited by: Chorus, I. and Bartram, J., St Edmundsbury Press, Bury St Edmunds, Suffolk, World Health Organization, New York, 275312, 1999.

Ikawa, M., Phillips, N., Haney, J. F., and Sasner, J. J.: Interference by plastics additives in the HPLC determination of microcystinLR and -YR, Toxicon, 37, 923-929, 1999.

International Organization for Standardization: Water quality - Determination of microcystins - Method using solid phase extraction (SPE) and high performance liquid chromatography (HPLC) with ultraviolet (UV) detection; International Organization for Standardization: Geneva, 2005.

Izydorczyk, K., Tarczynska, M., Jurczak, T., Mrowczynski, J., and Zalewski, M.: Measurement of phycocyanin fluorescence as an online early warning system for cyanobacteria in reservoir intake water, Environ. Toxicol., 20, 425-430, 2005.

Kenefick, S. L., Hrudey, S. E., Peterson, H. G., and Prepas, E. E.: Toxin release from Microcystis aeruginosa after chemical treatment, Water Sci. Technol., 27, 433-440, 1993.

Kurmayer, R.: The toxic cyanobacterium Nostoc sp. strain 152 produces highest amounts of microcystin and nostophycin under stress conditions, J. Phycol., 47, 200-207, 2011. 
Lam, A. K. Y., Fedorak, P. M., and Prepas, E. E.: Biotransfemation of the cyanobacterial hepatotoxin microcystin-U1, as determined by HPLC and protein phosphatase bioassay, Environ. Sci. Technol., 29, 242-246, 1995.

Lawton, L. A., Edwards, C., and Codd, G. A.: Extraction and highperformance liquid-chromatographic method for the determination of microcystins in raw and treated waters, Analyst, 119, 1525-1530, 1994.

Liu, G. L., Qian, Y., Dai, S. G., and Feng, N.: Adsorption of microcystin LR and LW on suspended particulate matter (SPM) at different pH, Water Air Soil Pollut., 192, 67-76, 2008.

Martins, J., Peixe, L., and Vasconcelos, V. M.: Unraveling cyanobacteria ecology in wastewater treatment plants (WWTP), Microbbiol. Ecol., 62, 241-256, 2011.

Masojídek, J., Avigad Vonshak, A., and Torzillo, G.: Chlorophyll Fluorescence Applications in Microalgal Mass Cultures, in: Chlorophyll a Fluorescence in Aquatic Sciences: Methods and Applications, edited by: Suggett, D. J., Prâaésil, O., and Borowitzka, M. A., Springer, Dordrecht, The Netherlands, 2011.

Matthijs, H. C. P., Visser, P. M., Reeze, B., Meeuse, J., Slot, P. C., Wijn, G., Talens, R., and Huisman, J.: Selective suppression of harmful cyanobacteria in an entire lake with hydrogen peroxide, Water Res., 46, 1460-1472, 2012.

Meriluoto, J. and Spoof, L.: SOP: Analysis of microcystins by high-performance liquid chromatography with photodiode-array detection, in: Toxic: cyanobacterial monitoring and cyanotoxin analysis, edited by: Meriluoto, J. and Codd, G. A., Åbo Akademi University Press, Åbo, Finland, 77-84, 2005.

Moldaenke, C.: Online fluorescence measurements for monitoring of raw waters and drinking water treatment processes from algae (cyanobacteria) like waters; bbe Moldaenke GmbH: Kronshagen, Germany, 2009.

Passarge, J., Hol, S., Escher, M., and Huisman, J.: Competition for nutrients and light: Stable coexistence, alternative stable states, or competitive exclusion?, Ecol. Monogr., 76, 57-72, 2006.

Richardson, T. L., Lawrenz, E., Pinckney, J. L., Guajardo, R. C., Walker, E. A., Paerl, H. W., and MacIntyre, H. L.: Spectral fluorometric characterization of phytoplankton community composition using the Algae Online Analyser (R), Water Res., 44, 24612472, 2010.
Samuilov, V. D., Bezryadnov, D. V., Gusev, M. V., Kitashov, A. V., and Fedorenko, T. A.: Hydrogen peroxide inhibits the growth of cyanobacteria, Biochemistry (Moscow), 64, 47-53, 1999.

Samuilov, V. D., Timofeev, K. N., Sinitsyn, S. V., and Bezryadnov, D. $\mathrm{V}$ : $\mathrm{H}_{2} \mathrm{O}_{2}$-induced inhibition of photosynthetic $\mathrm{O}_{2}$ evolution by Anabaena variabilis cells, Biochemistry (Moscow), 69, 926933, 2004.

Song, W. H., Bardowell, S., and O'Shea, K. E.: Mechanistic study and the influence of oxygen on the photosensitized transformations of microcystins (cyanotoxins), Environ. Sci. Technol., 41, 5336-5341, 2007.

Tchobanoglous, G., Burton, F. L., and Stensel, H. D.: Wastewater Engineering: Treatment and Reuse, 4th Edn., McGraw-Hill: New York, 2003.

Toze, S.: Reuse of effluent water - benefits and risks, Agr. Water Manage., 80, 147-159, 2006.

Tsuji, K., Watanuki, T., Kondo, F., Watanabe, M. F., Suzuki, S., Nakazawa, H., Suzuki, M., Uchida, H., and Harada, K.: Stability of microcystins from cyanobacteria 2. Effect of UV light on decomposition and isomerization, Toxicon, 33, 1619-1631, 1994.

Vasconcelos, V. M. and Pereira, E.: Cyanobacteria diversity and toxicity in a wastewater treatment plant (Portugal), Water Res., 35, 1354-1357, 2001.

Wang, J. X., Xie, P., and Guo, N.: Effects of nonylphenol on the growth and microcystin production of Microcystis strains, Environ. Res., 103, 70-78, 2007.

Welker, M. and Steinberg, C.: Indirect photolysis of cyanotoxins: One possible mechanism for their low persistence, Water Res., 33, 1159-1164, 1999.

Welker, M. and Steinberg, C.: Rates of humic substance photosensitized degradation of microcystin-LR in natural waters, Environ. Sci. Technol., 34, 3415-3419, 2000.

Wood, S. A., Dietrich, D. R., Cary, S. C., and Hamilton, D. P.: Increasing Microcystis cell density enhances microcystin synthesis: a mesocosm study, Inland Waters, 2, 17-22, 2012.

World Health Organization: Algae and Cyanobacteria in Fresh Water, in: Guidelines for Safe Recreational Water Environments: Vol. 1: Coastal and freshwaters, World Health Organization, Geneva, 136-158, 2003. 